\title{
Performance of Two Sugar Beet Varieties under Fertilization with Potassium and Foliar Spraying with Micronutrients
}

\author{
A. A. A. Mekdad and A. M. A. El-Sherif \\ Agronomy Department, Faculty of Agriculture, Fayoum \\ University, Fayoum, Egypt.
}

\begin{abstract}
T WO FIELD experiments conducted during 2013/14 and 2014/15 1 seasons to study the effect of three potassium levels i.e., $0\left(\mathrm{~K}_{1}\right)$, $25\left(\mathrm{~K}_{2}\right)$ and $50\left(\mathrm{~K}_{3}\right) \mathrm{kg} \mathrm{K} /$ fed and five foliar spraying with mixture of micronutrients $(B+Z n) T_{1},(B+M n) T_{2},(Z n+M n) T_{3},(B+Z n+M n) T_{4}$ and (water as a control) $\mathrm{T}_{5}$ on yield and its attributes of two sugar beet varieties i.e., Farida $\left(\mathrm{V}_{1}\right)$ and Demo $\left(\mathrm{V}_{2}\right)$. The experimental design was a split-split plot in RCBD with three replications where varieties, potassium levels and micronutrients were allocated in the main, sub and sub-sub plots, respectively.
\end{abstract}

Results indicated that potassium and foliar spray with micronutrients mixture fertilization had a highly significant $(\mathrm{P} \leq 0.01)$ positive effect on yield, yield components and quality traits, varieties differed significantly in root length, root fresh weight, yields in terms of root, top biological, gross sugar and extractable sugar, as well as harvest index in both seasons.

The highest yields of root and top were $53.25 \& 49.96,15.21$ and $15.55 \mathrm{t} / \mathrm{fad}\left(\mathrm{fad}=\right.$ faddan $\left.=4200 \mathrm{~m}^{2}\right)$ in both seasons, respectively as well as, root fresh weight $(2661.50 \mathrm{~g} / \mathrm{plant})$ and extractable sugar yield $(12.67 \mathrm{t} / \mathrm{fad})$ in the first season were obtained by Demo (V2) variety with $50 \mathrm{~kg} \mathrm{~K} / \mathrm{fad}(\mathrm{K} 3)$ with mixture of micronutrients B+Zn+Mn (M4). Correlation analysis revealed the presence of highly significant $r$ values between gross sugar yield with each of root yield and gross sugar $(\%)$.

Keywords: Sugar beet varieties, Potassium, Microelements, Yield and Quality.

Sugar is a key item to different nations of the world, since it comes directly after wheat from the vital significance perspective in numerous nations of Europe, Africa, North and South America and Australia. While, it possesses the $2^{\text {nd }}$ order after rice in Asian nations. Sugar varies than any other food commodity in being consumed every day at different rates by all people regardless of their standards or classes. In addition to the direct consumption of sugar, it is likewise utilized as a part of numerous chemicals, painting materials and other industries.

It is worth mentioning that due to limited water resources and arable area that characterized with reasonable environmental conditions required for cane 
plantation, together with increasing magnitude of the total demand in sugar, it becomes necessary to pay more consideration to sugar beet crop.

Sugar beet crop, (Beta vulgaris L.) is occupied the $2^{\text {nd }}$ position for sugar production in Egypt and in a lot of nations everywhere the world. Agriculture policy of Egypt supports sugar beet cultivators, to increase the cultivated area so increase sugar production and decrease the gap between production and consumption of sugar.

Selecting the promising varieties and their appropriate potassium fertilization as well as effective micronutrients are very essential parameters in sugar yield and quality. It is obvious that yield is the product of the genetic composition and environmental condition prevailing during plant growth. The genetic pattern is relatively fixed for a given variety but the environment affects the development through its interaction with genetic composition. Refay (2010) showed that fresh and dry root weight and other yield quality parameters in addition to chemical composition of roots were greater for Samo-2 variety as compared to those other two Univers and Samo-1. He included that, the superiority of Samo-2 variety may be attributed to its genetic made up. Safina et al. (2012) demonstrated that cultivars of sugar beet significantly varied in productivity. Demo variety gave the highest root and greatest sugar yield.

Potassium is the $3^{\text {rd }}$ most important element for plant growth and development. It is an essential nutrient required in higher amounts for plant metabolism especially photosynthesis and assimilates transport (Wang et al., 2015). EL-Harriri \& Gobarh (2001) noted that high level of potassium (48 kg $\mathrm{K}_{2} \mathrm{O} / \mathrm{fed}$ ) exhibited a significant increase on LAI, root dimension, root and top yields/fad, sucrose and purity $\%$ as compared with control treatment. Ouda (2001) cleared that applied the highest level of potassium $48 \mathrm{~kg} \mathrm{~K} 2 \mathrm{O} / \mathrm{fad}$ sustained a significant increase in root dimension, root and foliage weights/plant, root, top and sugar yields/fad and sucrose $\%$.

Abdel-Mawly \& Zanouny (2004) reported that using the high level of potassium caused to increasing percentage of purity as well as root and foliage yield of sugar beet plants. Amer et al. (2004) reported that using $90 \mathrm{~kg} \mathrm{~K}_{2} \mathrm{O} / \mathrm{fad}$ of potassium increase significantly the percentage of nitrogen, potassium, phosphors, sucrose and purity in sugar beet root additionally yield of root and sugar. Mehrandish et al. (2012) noted that utilizing potassium gave the highest values of yield in terms of root, top and sugar. They included that utilizing of $100 \mathrm{~kg} \mathrm{~K}_{2} \mathrm{O} \mathrm{ha}^{-1}$ enhanced quantity and quality traits of sugar beet. Neseim et al. (2014) reported that utilization $100 \mathrm{~kg} / \mathrm{fad}$ of $\mathrm{K}\left(48 \% \mathrm{~K}_{2} \mathrm{O}\right)$ encouraged to give the highest root yield and sugar yield, percentage of sucrose, sodium, potassium and alpha-amino $\mathrm{N}$.

Micronutrients often act as co-factors in enzyme activating and participating in redox responses, photosynthesis and respiration. It has vital function in cell development and connected with sugar translocate process (Yarnia et al., 2008). Utilization of micronutrients like manganese, zinc and iron with balance can Egypt. J. Agron. 38, No.2 (2016) 
enhance productivity of sugar beet (Mousavi et al., 2007). The most studied of all the microelements on sugar beet examined the effect of manganese insufficient on yield and quality.

Cooke \& Scott (1993) revealed that sugar beet yield and quality significantly decreased with insufficient supply of boron. Mekdad (2015) noted that utilization of $120\left(\mathrm{~B}_{4}\right)$ and $150\left(\mathrm{~B}_{5}\right)$ ppm of boron significantly enhanced root yield and quality of sugar beet. On the other hand $\mathrm{Na}, \mathrm{K}$, alpha-amino $\mathrm{N}$, loss sugar percentages, harvest index and loss sugar yield were diminished.

Zinc is consider the vital microelements and has specific physiological functions in all living systems, for example the maintenance of structural and functional integrity of biological membranes and facilitation of protein synthesis, gene expression also, is considered the most limiting element for productivity crops in various regions of the world. Kobraee et al. (2011) recommended that zinc shortage seem a lot of common microelements reduction case in crops around the world, give rise to decrease in yield and quality. Barłóg et al. (2016), reported that increasing of $\mathrm{Zn}$ fertilization caused increase sugar beet yield.

Mekdad \& Rady (2016) showed that adding micronutrient mixtures $(\mathrm{Fe}+\mathrm{Zn}+$ $\mathrm{Mn}$ ) improved yield and its attributes of sugar beet crop.

The aim of this work was to determine the effects of applying fertilizers containing potassium levels and foliar spraying with different micronutrients mixtures, i.e., manganese (Mn), zinc ( $\mathrm{Zn}$ ) and boron (B) on plant characteristics, quality and yield traits of two sugar beet varieties.

\section{Materials and Methods}

Two field experiments were carried out in the farm of the Faculty of Agriculture, Demo $\left(29^{\circ} 17^{`} \mathrm{~N} ; 30^{\circ} 53^{`} \mathrm{E}\right)$, Fayoum University, Egypt, during the two successive winter seasons of 2013/14 and 2014/15. The objective of this investigation was to study the effect of potassium levels and foliar spraying with different micronutrients manganese $(\mathrm{Mn})$, zinc $(\mathrm{Zn})$ and boron (B) on plant characteristics, quality and yield traits of two multigerm sugar beet varieties, i.e., Farida and Demo. Each experimental basic unit included 5 ridges, $60 \mathrm{~cm}$ apart and $3.5 \mathrm{~m}$ long, comprising an area of $10.5 \mathrm{~m}^{2}$ (1/400 fad). The preceding summer crop was corn (Zea mays L.) in both seasons. Experiments were sown on September $13^{\text {th }}$ and $21^{\text {st }}$ in the first and second seasons, respectively.

The recommended agricultural practices for growing sugar beet were followed except the factors under study which arranged in split-split plot in randomized complete block design with three replications. The main plots were assigned to multigerm sugar beet varieties viz. Farida $\left(\mathrm{V}_{1}\right)$ and Demo $\left(\mathrm{V}_{2}\right)$. Potassium sulphate $\left(48 \% \mathrm{~K}_{2} \mathrm{O}\right)$ applied to the soil in granular form at the level of $0\left(\mathrm{~K}_{1}\right), 25\left(\mathrm{~K}_{2}\right)$ and $50\left(\mathrm{~K}_{3}\right) \mathrm{kg} \mathrm{K} \mathrm{SO}_{4} \backslash \mathrm{fad}$ were arranged in the sub treatments and applied in three equal doses, i.e., after thinning (at 4-6 leaf stage), before the second and the third 
irrigation (surface irrigation as recommended). The sub-sub plots were occupied with five combinations of micronutrients. $\mathrm{T}_{1}(\mathrm{~B}+\mathrm{Zn}), \mathrm{T}_{2}(\mathrm{~B}+\mathrm{Mn}), \mathrm{T}_{3}(\mathrm{Zn}+\mathrm{Mn}), \mathrm{T}_{4}$ $(\mathrm{B}+\mathrm{Zn}+\mathrm{Mn})$ and $\mathrm{T}_{5}$ (spraying with water as control) at $100 \mathrm{ppm}$ for each in the form of zinc sulphate, manganese sulphate and boric acid. Micronutrients were applied as foliar spray in two times (80 and 110 days) from sowing. The foliar solutions volume was $200 \mathrm{~L} /$ fad conducted by hand sprayer. Physical and chemical analysis of soil at the experimental site in both seasons of study are presented in Table 1-a, Monthly weather data at Fayoum, Egypt as average for two growing seasons 2013/2014 and 2014/2015 of study are presented in Table 1-b.

TABLE 1-a. Particle size distribution and some chemical properties of the experimental soil in 2013/2014 and 2014/2015 seasons.

\begin{tabular}{|c|c|c|c|c|}
\hline \multicolumn{3}{|l|}{ Season } & $2013 / 2014$ & $2014 / 2015$ \\
\hline \multicolumn{3}{|l|}{ Sand\% } & 66.5 & 76.1 \\
\hline \multicolumn{3}{|l|}{ Silt $\%$} & 12.4 & 10.8 \\
\hline \multicolumn{3}{|c|}{ Clay\% } & 21.1 & 13.1 \\
\hline \multicolumn{3}{|c|}{ Soil texture class } & Sandy clay Loam & Sandy Loam \\
\hline \multicolumn{3}{|c|}{$\mathrm{CaCO} 3 \%$} & 7.10 & 5.20 \\
\hline \multirow{4}{*}{ Cations } & \multirow{8}{*}{$\mathrm{MeqL}^{-1}$} & $\mathrm{Na}^{+}$ & 69.80 & 56.70 \\
\hline & & $\mathrm{K}^{+}$ & 2.82 & 1.40 \\
\hline & & $\mathrm{Mg}^{+2}$ & 25.00 & 11.0 \\
\hline & & $\mathrm{Ca}^{+2}$ & 30.88 & 60.62 \\
\hline \multirow{4}{*}{ Anions } & & $\mathrm{SO}_{4}^{-2}$ & 28.60 & 33.40 \\
\hline & & $\mathrm{CL}^{-}$ & 92.40 & 86.32 \\
\hline & & $\mathrm{HCO}^{-}$ & 7.50 & 10.0 \\
\hline & & $\mathrm{CO}^{-2}$ & - & - \\
\hline \multicolumn{3}{|c|}{ Organic matter \% } & 1.47 & 0.70 \\
\hline \multicolumn{3}{|c|}{ ECe, $\mathrm{dSm}^{-1}$ at $25 \mathrm{C}^{\mathrm{o}}$} & 5.89 & 5.33 \\
\hline \multicolumn{3}{|c|}{$\mathrm{pH}$ at $25 \mathrm{C}^{\circ}$} & 7.63 & 7.87 \\
\hline \multirow{4}{*}{\multicolumn{2}{|c|}{$\begin{array}{l}\text { Micronutrients } \\
\quad(\mathrm{ppm})\end{array}$}} & $\mathrm{Fe}$ & 6.86 & 4.29 \\
\hline & & $\mathrm{Mn}$ & 4.21 & 3.57 \\
\hline & & $\mathrm{Cu}$ & 1.46 & 0.69 \\
\hline & & $\mathrm{Zn}$ & 1.10 & 0.29 \\
\hline
\end{tabular}

TABLE 1-b. Monthly weather data at Fayoum, Egypt as average for two growing seasons 2013/2014 and 2014/2015.

\begin{tabular}{|l|c|c|c|c|c|c|c|c|}
\hline \multirow{4}{*}{ Month } & \multicolumn{2}{|c|}{${ }^{*} \mathbf{T}_{\min }\left(\mathbf{C}^{\circ}\right)$} & \multicolumn{2}{c|}{${ }^{*} \mathbf{T}_{\max }\left(\mathbf{C}^{0}\right)$} & \multicolumn{2}{c|}{${ }^{* *} \mathbf{R H}_{\min }(\boldsymbol{\%})$} & \multicolumn{2}{c|}{${ }^{* *} \mathbf{R H}_{\max }(\boldsymbol{\%})$} \\
\cline { 2 - 10 } & $2013 /$ & $2014 /$ & $2013 /$ & $2014 /$ & $2013 /$ & $2014 /$ & $2013 /$ & $2014 /$ \\
& 2014 & 2015 & 2014 & 2015 & 2014 & 2015 & 2014 & 2015 \\
\hline September & 23.60 & 24.40 & 36.60 & 38.40 & 14.00 & 17.40 & 74.00 & 74.50 \\
\hline October & 19.50 & 21.50 & 30.80 & 34.80 & 18.60 & 19.50 & 68.03 & 75.97 \\
\hline November & 17.50 & 17.21 & 29.20 & 29.37 & 17.70 & 26.80 & 64.00 & 76.13 \\
\hline December & 12.22 & 12.60 & 25.80 & 26.10 & 23.30 & 25.50 & 66.20 & 77.10 \\
\hline January & 9.70 & 10.30 & 23.60 & 22.50 & 20.90 & 24.50 & 67.30 & 74.30 \\
\hline February & 11.20 & 10.50 & 25.90 & 23.60 & 22.60 & 24.00 & 67.90 & 74.00 \\
\hline March & 14.35 & 14.90 & 28.30 & 28.80 & 18.10 & 19.00 & 64.40 & 76.90 \\
\hline April & 15.40 & 15.70 & 30.40 & 32.80 & 9.30 & 14.90 & 60.90 & 75.10 \\
\hline May & 21.40 & 21.90 & 37.40 & 37.90 & 12.77 & 13.90 & 70.40 & 79.40 \\
\hline
\end{tabular}

*Tmin and *Tmax, are minimum and maximum temperatures, ${ }^{* * *}$ RHmin and ${ }^{* * *}$ RHmax are minimum and maximum relative humidity, respectively.

Egypt. J. Agron. 38, No.2 (2016) 


\section{The studied traits}

At harvest, (after 210 days from sowing) a random sample of five guarded plants in each sub-sub plot was taken. Samples were carried immediately to laboratory where roots washed to remove the soil particles. Plants were separated into tops and roots. For leaf area measurement, the disk method was followed using 300 disks of $300 \mathrm{~cm}^{2}$ area, according to Watson (1958), leaf blades weight was used for leaf area determination after excluding the petioles and midrib leaves.

LAI= Unit leaf area per plant $\left(\mathrm{cm}^{2}\right) /$ Plant ground area $\left(\mathrm{cm}^{2}\right)$

The following characters were determined at harvest:- Root length $(\mathrm{cm})$, root diameter $(\mathrm{cm})$, root fresh weight $(\mathrm{g} / \mathrm{plant})$ and top fresh weight $(\mathrm{g} / \mathrm{plant})$.

At harvest, plants of all ridges from each sub-subplot were harvested, cleaned, topped and weighed in plus weight of five plant sample and then it was converted to estimate:- Root yield ( $/ / f a d)$, top yield ( $t / f a d)$ and biological yield $(\mathrm{t} / \mathrm{fad})$. It was calculated by adding root yield together with top yield ( $/ / \mathrm{fad})$.

Harvest index (HI)

It was estimated by using the following equation:

$$
\mathrm{HI}=\frac{\text { Rootyield }(t / \text { fed })}{\text { Rootyield }(t / \text { fed })+\text { Topyield }(t / \text { fed })}
$$

Gross sugar yield ( $t / f a d$ )

It was estimated by multiplying root yield by gross sugar percentage.

White sugar yield ( $t / f a d$ )

It was estimated by multiplying root yield by white sugar percentage.

Losses sugar yield (t/fad)

It was estimated by multiplying root yield by loss sugar percentage.

All traits were determined in Delta Sugar Company Limited Laboratories at El-Hamoul, Kafr El-Sheikh Governorate according to the method of McGinnus (1971).

The traits of quality included

Gross sugar \%: Juice sugar content was determined according to McGinnus (1971).

White sugar \%: Extractable sugar content (white sugar) of beets was calculated according to Harvey \& Dotton (1993) as follows:

$$
\mathrm{ZB}=\text { pol-[0.343(K+NA) }+0.094 \mathrm{AmN}+0.29]
$$


where:

$\mathrm{ZB}=$ extractable sugar content $(\%$ per beet $)$ or white sugar

Pol = gross sugar $\%$

AmN $=\alpha$-amino-N determined by the "blue number method" was calculated by using the method of Sheikh Aleslami (1997).

Loss sugar \%: Loss sugar \% = gross sugar \% - white sugar $\%$

Juice purity percentage : Juice purity $\%(\mathrm{Qz})=\mathrm{ZB} / \mathrm{Pol}$ x100

The soluble non-sugars (potassium, sodium and alpha-amino nitrogen in meq/100 $\mathrm{g}$ of beet) in roots were determined by means of an Automatic Sugar Polarimetric.

All obtained data were statistically analyzed according to the technique of analysis of variance (ANOVA) for the split-split plot design as published by Gomez \& Gomez (1984), using GenStat $12^{\text {th }}$ edition. Least significant difference (LSD) method was used to test the differences between treatment means at $5 \%$ level of probability.

\section{Results and Discussions}

\section{Effect of two sugar beet varieties}

The tabulated results in Tables 2, 3 and 4 revealed that the two sugar beet varieties differed significantly in mean of root length $(\mathrm{cm})$, root fresh weight (g/plant), root, top, biological, gross and extractable sugar yield (t/fad) and harvest index $\%$ in both seasons. In addition to root diameter $(\mathrm{cm})$, sucrose and extractable sugar $\%$ in the $1^{\text {st }}$ season, also top fresh weight, purity $\%$ and loss sugar yield $(\mathrm{t} / \mathrm{fad})$ in the $2^{\text {nd }}$. While, varieties had no significant effect on leaf area $\left(\mathrm{cm}^{2}\right)$, leaf area index, as well as percentage of $\mathrm{Na}, \mathrm{K}, \alpha$-amino $\mathrm{N}$ and loss sugar in both seasons.

According to LSD test Demo $\left(\mathrm{V}_{2}\right)$ variety surpassed the other one where it produced higher values of root length $(32.78$ and $31.17 \mathrm{~cm})$, root fresh weight (1837.60 and $1820.29 \mathrm{~g} / \mathrm{plant}$ ), root yield (40.77 and $38.94 \mathrm{t} / \mathrm{fad})$, top yield (11.42 and $11.17 \mathrm{t} / \mathrm{fad})$, biological yield (52.19 and $50.11 \mathrm{t} / \mathrm{fad}$ ), gross sugar yield (8.18 and $7.69 \mathrm{t} / \mathrm{fad})$ and extractable sugar yield (7.40 and 7.00 $\mathrm{t} / \mathrm{fad})$ in the $1^{\text {st }}$ and $2^{\text {nd }}$ seasons, respectively, as well as root diameter $(16.18 \mathrm{~cm})$, sucrose $(19.74 \%)$ and extractable sugar $(17.85 \%)$ in the first season, also top fresh weight (1289.76 g/plant), purity $(90.70 \%)$ and loss sugar yield $(0.69 \mathrm{t} / \mathrm{fad})$ in the second season. On the contrary, Demo $\left(\mathrm{V}_{2}\right)$ variety produced significantly lowest value of harvest index $(0.78$ and $0.78 \%$ ) in both seasons, respectively. 
POTASSIUM AND MICRONUTRIENTS EFFECT ON SUGAR BEET ... 195

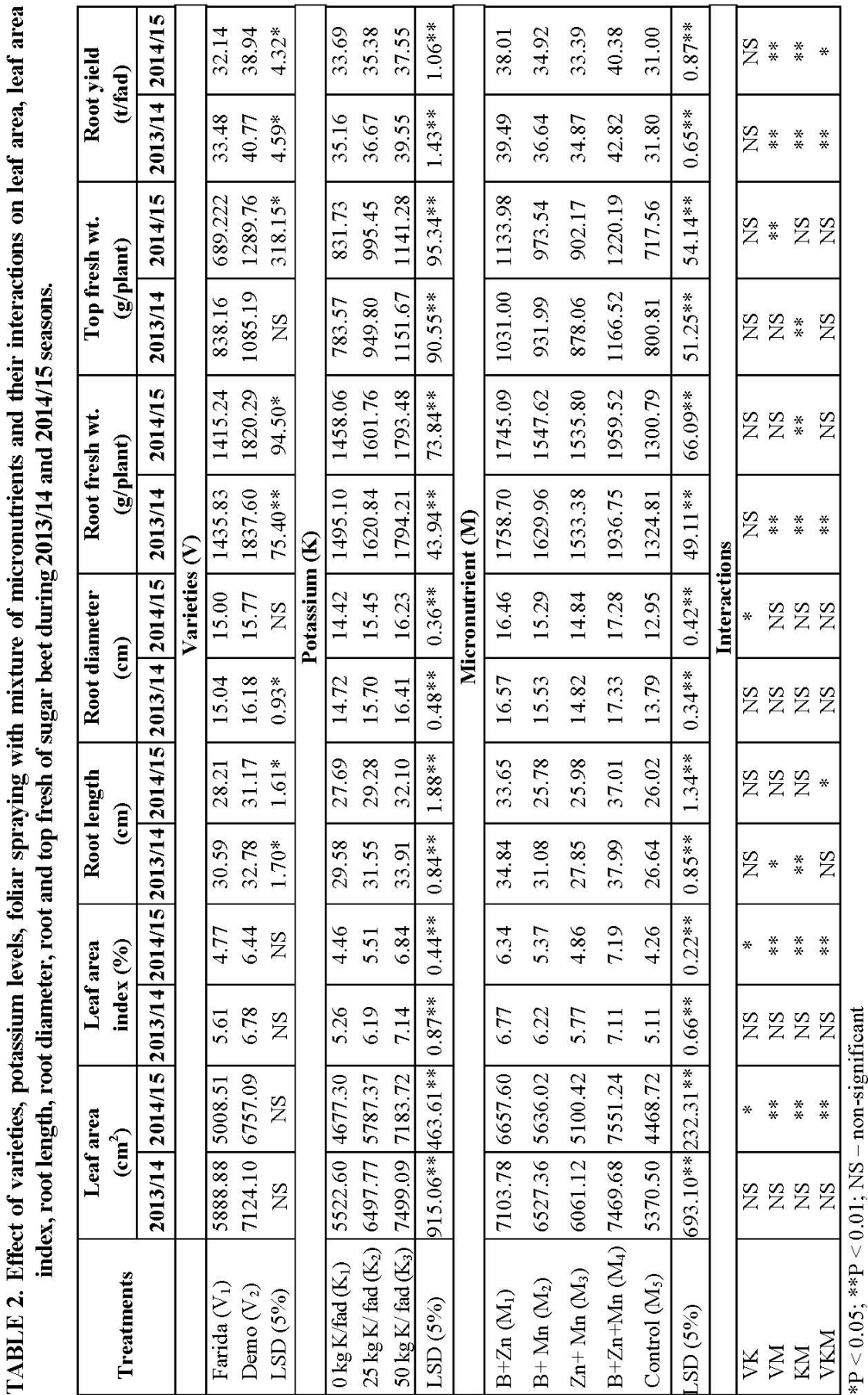




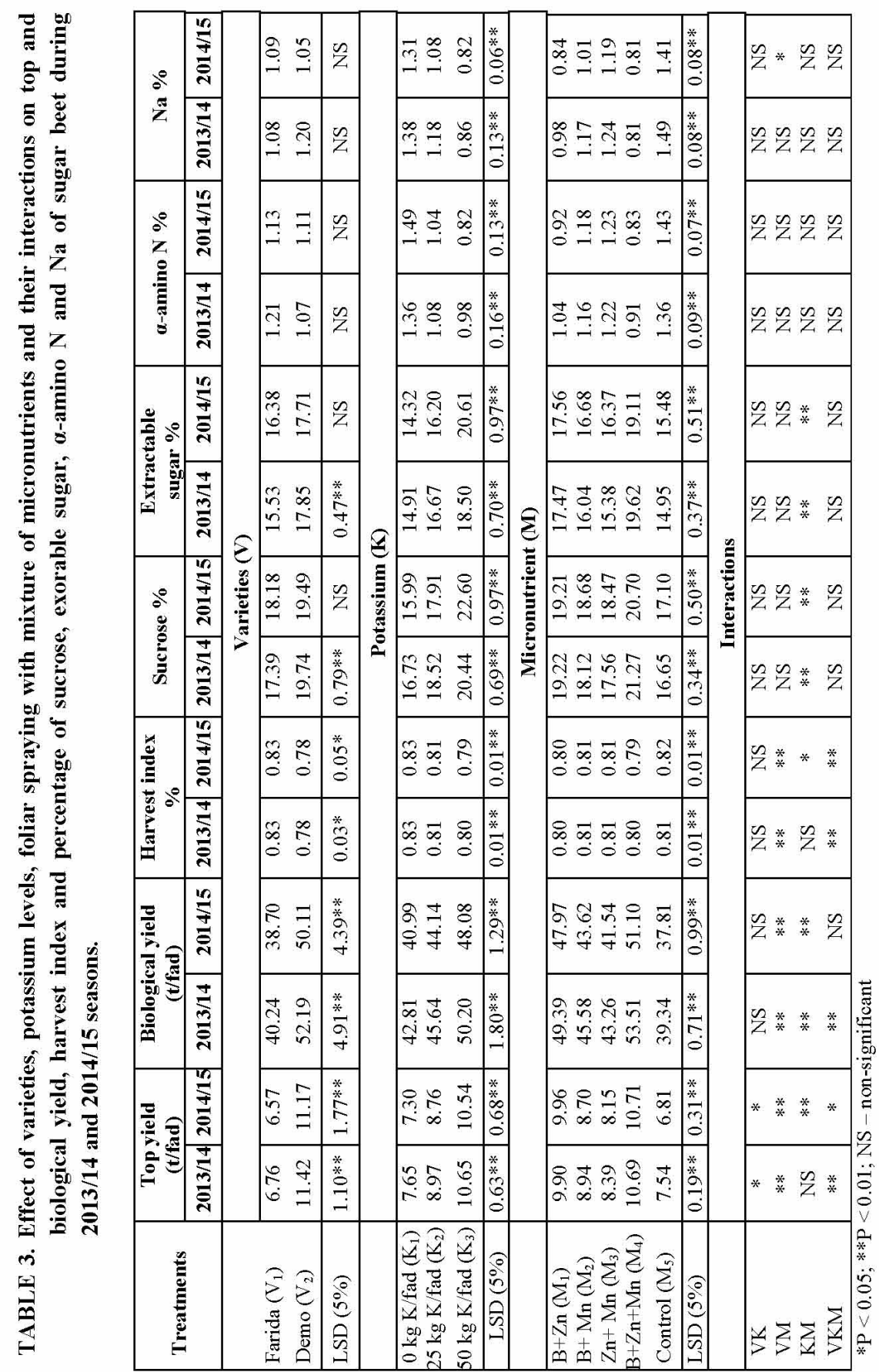

Egypt. J. Agron. 38, No.2 (2016) 


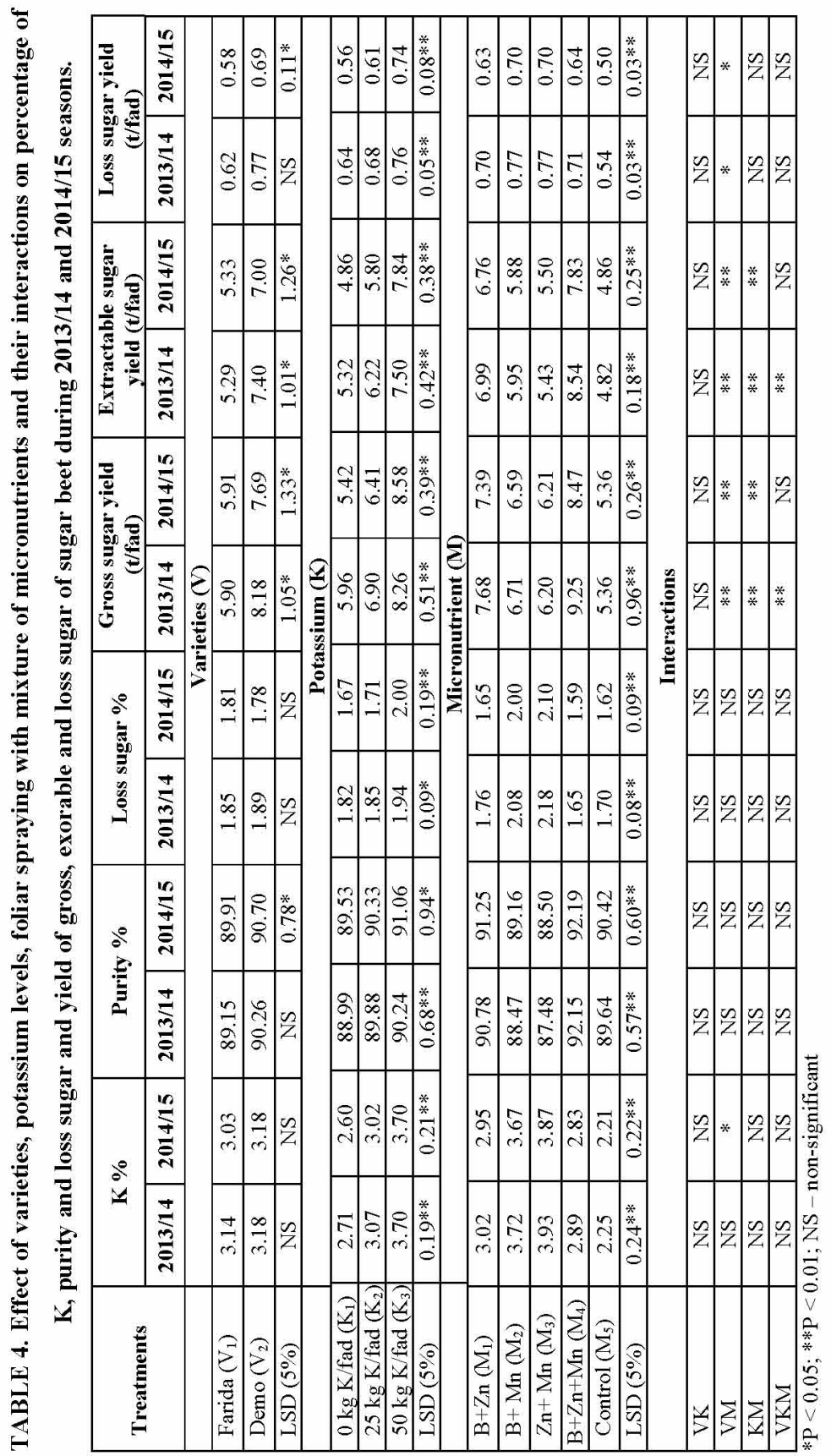

Egypt. J. Agron. 38, No.2 (2016) 
The superiority of variety Demo $\left(\mathrm{V}_{2}\right)$ in root yield might be due to its superiority in mean root dimensions and weight. Moreover, high root yield, gross and extractable sucrose (\%) from the same variety lead to high gross and extractable sugar yield (t/fad) during the two seasons. The superiority of Demo $\left(\mathrm{V}_{2}\right)$ variety might due to its increased photosynthetic efficiency. These effects are in agreement with those obtained by Masri (2008), Nasr \& Abd El- Razek (2008), Safina et al. (2012), Neamatollahi et al. (2013), Masri \& Hamza (2015) and Mekdad \& Rady (2016) who reported that root weight and yield as well as sucrose $\%$ and sugar yield were differed significantly by varies varieties.

\section{Effect of potassium levels}

It is evident from Tables 2, 3 and 4 that leaf area $\left(\mathrm{cm}^{2}\right)$, leaf area index, root dimension $(\mathrm{cm})$, root and top fresh weight (g/plant) as well as yields of root, top, biological, gross sugar, extractable sugar and loss sugar (tlfad) and harvest index were highly significant $(\mathrm{P} \leq 0.01)$ which affected by application of $50 \mathrm{~kg} \mathrm{~K} / \mathrm{fad}$ $\left(\mathrm{K}_{3}\right)$. Also, percentages of gross and extractable sugar, impurities in terms of sodium, potassium and alpha- amino $\mathrm{N}$, loss sugar and purity were highly significant which affected by the same level of potassium in 2013/14 and $2014 / 15$ seasons, except for loss sugar percentage in the 2013/14 season and purity $\%$ in the $2014 / 15$ season were significantly affected by application of 50 $\mathrm{kg} \mathrm{K} / \mathrm{fad}\left(\mathrm{K}_{3}\right)$.

It could be stated that application of the higher level of potassium $50 \mathrm{~kg}$ $\mathrm{K} /$ fad $\left(\mathrm{K}_{3}\right)$ significantly increased all studied yield, yield components and quality of sugar beet traits. However, harvest index (\%) was significantly decreased by the same level of potassium. It was noticed that applying $50 \mathrm{~kg} \mathrm{~K} / \mathrm{fad}\left(\mathrm{K}_{3}\right)$ caused significant increases in leaf area $\left(\mathrm{cm}^{2}\right) 35.79 \& 53.59 \%$, leaf area index $35.74 \& 53.36 \%$, root length $(\mathrm{cm}) 14.64 \& 15.93 \%$, root diameter $(\mathrm{cm}) 11.48 \&$ $12.55 \%$, root fresh weight (g/plant) $20.01 \& 23.00 \%$, top fresh weight (g/plant) $46.98 \& 37.22 \%$, yield ( $\mathrm{t} \backslash \mathrm{fad}$ ) of $\operatorname{root} 12.49 \& 11.46 \%$, top $39.22 \& 44.38 \%$, biological $17.26 \& 17.30 \%$, gross sugar $38.59 \& 58.30 \%$, extractable sugar $40.98 \& 61.32 \%$ and loss sugar $18.75 \& 32.14 \%$, as well as percentage of gross sugar $22.18 \& 41.34 \%$, extractable sugar $24.08 \& 43.92 \%$, K $36.53 \& 42.31 \%$, purity $1.40 \& 1.71 \%$ and loss sugar $6.59 \& 19.76 \%$ in the first and second season, respectively compared with $0 \mathrm{~kg} \mathrm{~K} / \mathrm{fad}\left(\mathrm{K}_{1}\right)$. On the contrary, harvest index, $\alpha$ - amino $\mathrm{N}, \mathrm{Na}(\%)$ of the crop received $50 \mathrm{~kg} \mathrm{~K} / \mathrm{fad}\left(\mathrm{K}_{3}\right)$ were significantly decreased by $3.61 \& 4.82 ; 27.24 \& 44.97 ; 37.68$ and $37.40 \%$ in the two season, respectively, compared to $0 \mathrm{~kg} \mathrm{~K} / \mathrm{fad}\left(\mathrm{K}_{1}\right)$. Overall, potassium fertilizer application of $50 \mathrm{~kg} \mathrm{~K} / \mathrm{fad}\left(\mathrm{K}_{3}\right)$ gave the highest values for all parameters under studied, except harvest index, $\alpha$ - amino $\mathrm{N}$, and $\mathrm{Na}(\%)$.

Such increment in root yield obtained from utilizing potassium with level of $50 \mathrm{~kg} \mathrm{~K} \mathrm{~K}_{2} \mathrm{O} / \mathrm{fad}$ can be ascribed to enhance beet growth, in terms of longer, thicker and heavier roots weight, though $\mathrm{K}$ plays a essential role in many physiological and biochemical processes for example, cell division and Egypt. J. Agron. 38, No.2 (2016) 
elongation. Besides, utilization of $\mathrm{K}$ with level $50 \mathrm{~kg} \mathrm{~K} 2 \mathrm{O} /$ fad increased top yield through increasing leaf area. These effects are in harmony with those reported by Zengin et al. (2009), Abo- Shady et al. (2010), Nafei et al. (2010), Mehrandish et al. (2012) and Salami \& Saadat ( 2013).

The positive effect of $\mathrm{K}$ fertilizer which improved gross and extractable sugar yield $(\mathrm{t} / \mathrm{fad})$ and quality traits may be due to the necessary function of $\mathrm{K}$ in building up metabolites and sugars accumulation which convey from leaves to roots, thus improved root and quality traits (Nitoses \& Evans, 1969). Russell et al. (1971) reported that the positive effect of the function of using $\mathrm{K}$ fertilizer in enhancing quality and extractable sugar additionally root yield.

Effect of foliar spray with combinations of micronutrients

Results in Tables 2, 3 and 4 indicated that foliar spray with micronutrients mixture had a highly significant positive effect on yield, yield components and quality traits. Application mixture of all micronutrients $\mathrm{B}+\mathrm{Zn}+\mathrm{Mn}\left(\mathrm{M}_{4}\right)$ surpassed other treatments followed by $\mathrm{B}+\mathrm{Mn}\left(\mathrm{M}_{1}\right)$ affecting all studied traits in comparison with untreated plants $\left(\mathrm{M}_{5}\right)$ sprayed with water as a control in both seasons. It was noticed that compared with control treatment, applying mixture of all micronutrients $\mathrm{B}+\mathrm{Zn}+\mathrm{Mn}\left(\mathrm{M}_{4}\right)$ caused significant increases in leaf area $\left(\mathrm{cm}^{2}\right) 39.09 \& 68.98 \%$, leaf area index $39.14 \& 68.78 \%$, root length $(\mathrm{cm}) 29.88$ $\& 42.24 \%$, diameter $(\mathrm{cm}) 25.67 \& 33.44 \%$, root fresh weight (g/plant) $46.19 \&$ $50.64 \%$, top fresh weight (g/plant) $45.67 \& 70.05 \%$, yields $(\mathrm{t} / \mathrm{fad})$ in terms of root $34.65 \& 30.26 \%$, top $41.78 \& 57.27 \%$, biological $36.02 \& 35.15 \%$, gross sugar $72.57 \& 58.02 \%$ and extractable sugar $77.18 \& 61.11 \%$, as well as percentage of sucrose $27.75 \& 21.05 \%$, extractable sugar $31.24 \& 23.45 \%$ and purity $2.80 \& 1.96 \%$. On the other hand, in the 2013/14 and 2014/15 seasons, respectively it caused significant decreases in harvest index $1.23 \& 3.66 \%, \mathrm{Na}$ $45.64 \& 43.26 \%$ and $\alpha$-amino-N 33.09 and $41.10 \%$.

It was clearly that, positive effect of boron element in combinations $\left(\mathrm{M}_{4}\right.$ and $\mathrm{M}_{1}$ ) on yield and its attributes. Similar results were obtained by Mekdad (2015) who noted that root yield and percentage of gross and extractable sugar were significantly increased by using boron in sugar beet.

These findings are in line with those obtained by Gobarah et al. (2014). Mekki (2014) reported that utilization of $2 \%$ Urea, $400 \mathrm{ppm} \mathrm{Zn}$ or $\mathrm{Mn}$ independently furthermore, in mixing significantly increased root dimension, fresh root weigh, yields of root, top and sugar $(\mathrm{t} / \mathrm{fad})$ contrasted to control treatment. He added that the percentages of sucrose, purity, sodium and potassium contents were increased with using microelements as foliar spray in comparison to control treatment. This is because $\mathrm{Zn}$ and $\mathrm{Mn}$ are main elements for crop production. Foliar spraying with various micronutrients elements that caused to a positive increase in sucrose, purity and extractable sugar (\%) are reported by Jaszczolt (1998) and Gobarah \& Mekki (2005). 
Mekdad \& Rady (2016) found that foliar spray with the micronutrient mixture had significant positive effects on sugar beet yield and quality parameters. Utilization of $(\mathrm{Fe}+\mathrm{Zn}+\mathrm{Mn})$ significantly surpassed the (control; tap water) in leaf area index, root dimension, root and top fresh weights, root and white sugar yields and purity in both seasons. However, it caused a significant depress in harvest index.

\section{Interaction effects}

Effect of the bilateral interaction between the two sugar beet varieties and potassium levels

Data illustrated in Tables 2 and 3 revealed that the mean top yield (t/fad) was significantly affected by the interaction between application of the two sugar beet varieties and potassium levels in both seasons, while leaf area $\left(\mathrm{cm}^{2}\right)$, LAI and root diameter $(\mathrm{cm})$ only in $2^{\text {nd }}$ season.

Effect of the bilateral interaction between the two sugar beet varieties and foliar spray with combinations of micronutrients

Results in Tables 2,3 and 4 indicated that yields of root, top, biological, gross sugar, extractable sugar and loss sugar (t/fad) and harvest index \% in 2013/14 and 214/15 seasons, while root length, root fresh weight in the first season, leaf area, leaf area index, top fresh weight, $\mathrm{Na}$ and $\mathrm{K}$ in the second season were significantly affected by the interaction between application of the two sugar beet varieties and foliar spray with mixture micronutrients. These results are in agreement with those obtained by Masri \& Hamza (2015) who reported that root weight, root yield, purity $\%$, white sugar $\%$ and sugar yield were significantly influenced by the interaction between utilization of micronutrients mixture and sugar beet cultivars in the two seasons of their study.

Effect of the bilateral interaction between potassium levels and foliar spray with combinations of micronutrients

Data illustrated in Tables 2, 3 and 4 reveal that the mean root fresh weight, yields of root, biological gross and extractable and percentage of sucrose and extractable sugar in 2013/14 and 2014/15 seasons, besides root length and top fresh weight in the first season, in addition to, leaf area, leaf area index, top yield and harvest index in the second one were significantly affected by the interaction between application of potassium levels and foliar spray with combinations of micronutrients.

Effect of the trilateral interaction among the two sugar beet varieties, potassium levels and foliar spray with combinations of micronutrients

The data presented in Tables 2, 3 and 4 show the differences root and top yield as well as, harvest index in 2013/14 and 2014/15 seasons, as well as, root fresh weight and yield of biological, gross and extractable (\%) in the first season, while leaf area, leaf area index and root length in the second season due to the Egypt. J. Agron. 38, No.2 (2016) 
interaction among the three factors were significant. The highest yields of root and top were $53.25 \& 49.96,15.21$ and $15.55 \mathrm{t} / \mathrm{fad}$ in both seasons, respectively which are presented in Fig. 1 and 2 , as well as root fresh weight $(2661.50$ g/plant) in Fig. 3 and extractable sugar yield (12.67 t/fad) in the first season in Fig. 4 were obtained by Demo $\left(\mathrm{V}_{2}\right)$ variety with $50 \mathrm{~kg} \mathrm{~K} / \mathrm{fad}\left(\mathrm{K}_{3}\right)$ with mixture of micronutrients $\mathrm{B}+\mathrm{Zn}+\mathrm{Mn}\left(\mathrm{M}_{4}\right)$.

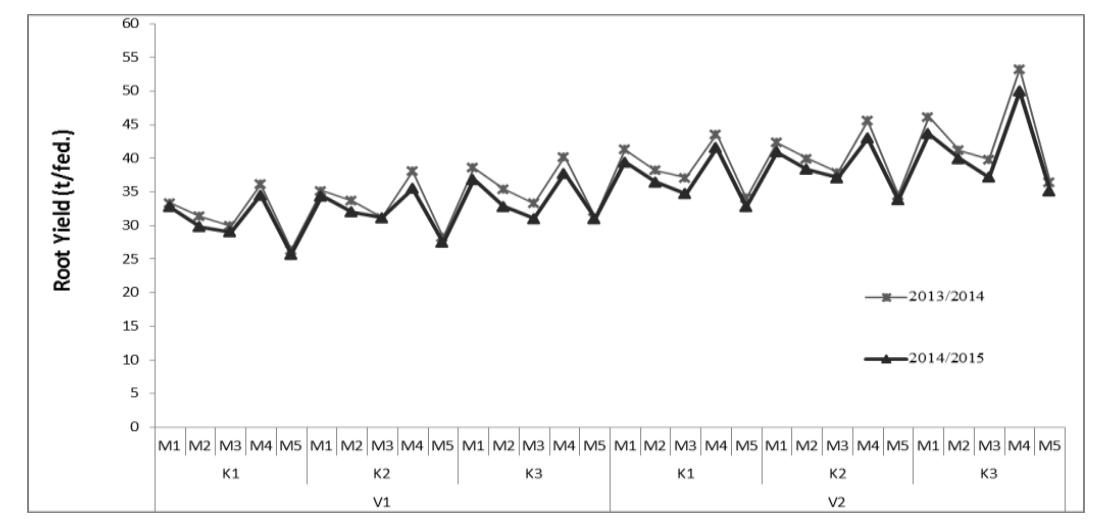

Fig. 1. Effect of interactions between varieties, potassium levels and foliar spraying on root yield ( $t /$ fad) in $2013 / 2014$ and $2014 / 2015$ seasons.

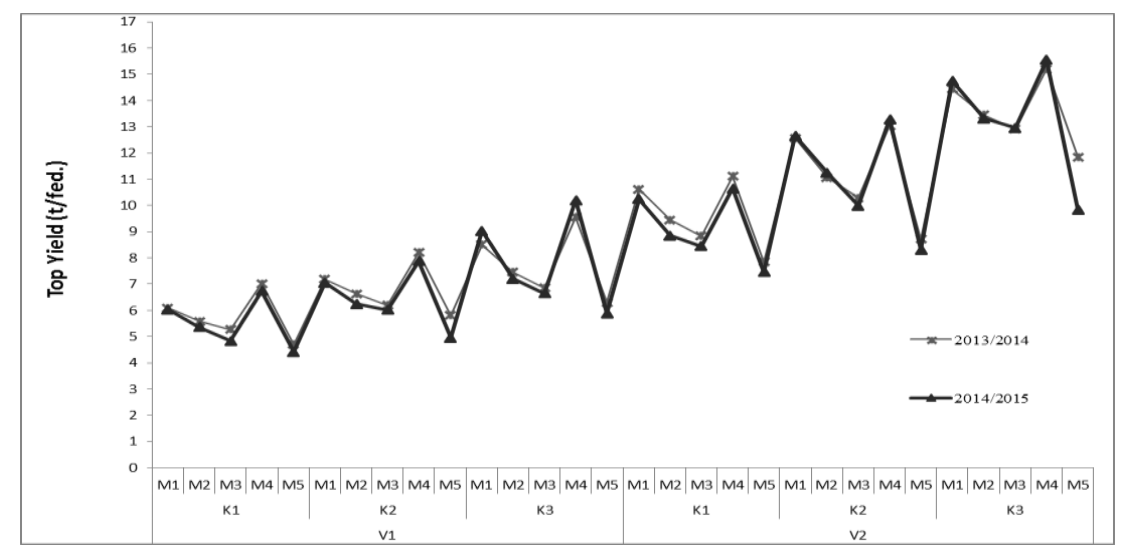

Fig. 2. Effect of interactions between varieties, potassium levels and foliar spraying on top yield (t/fad) in 2013/2014 and 2014/2015 seasons. 


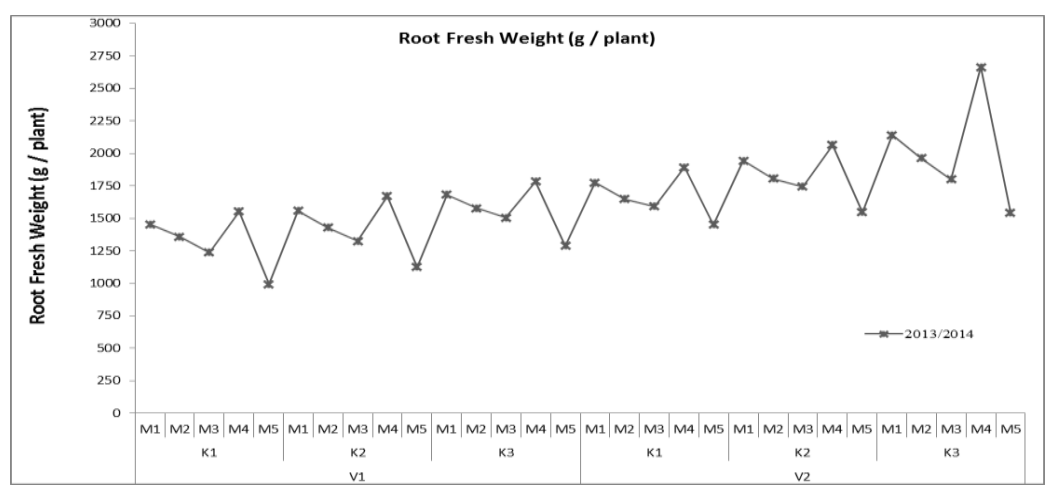

Fig. 3. Effect of interactions between varieties, potassium levels and foliar spraying on root fresh weight (g/plant) in $2013 / 2014$ season.

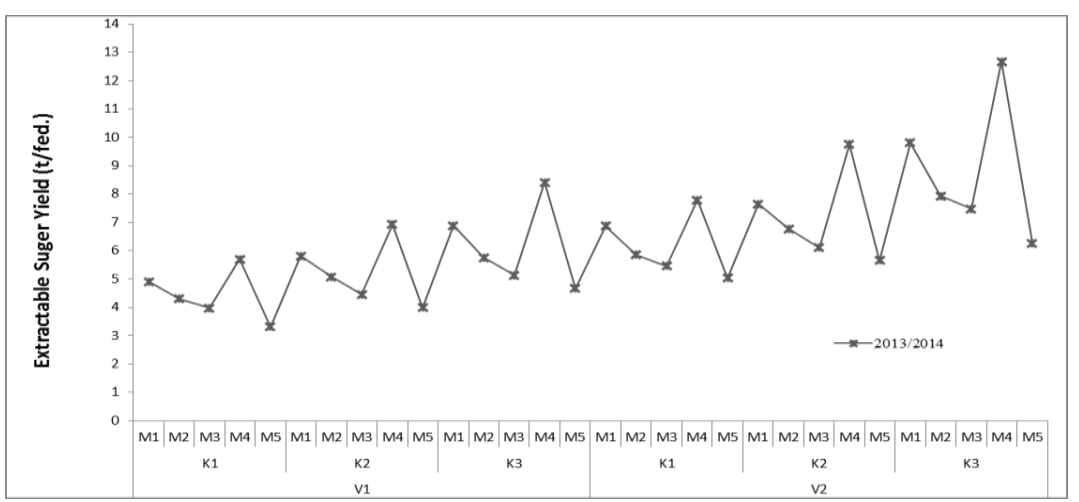

Fig. 4. Effect of interactions between varieties, potassium levels and foliar spraying on extractable sugar yield ( $t /$ fad) in 2013/2014 season.

\section{Correlation analysis of yield and its attributes}

The correlation coefficients in Table 5 between gross sugar yield (t/fad) and each of root length and diameter $(\mathrm{cm})$, root fresh weight $(\mathrm{g} / \mathrm{plant})$, root yield $(\mathrm{t} / \mathrm{fad})$ and gross sugar $(\%)$ were computed in order to throw light on the relationship of effectual traits interest. Positive and highly significant $(\mathrm{P} \leq 0.01)$ correlation coefficients were obtained between gross sugar yield and each of root yield $\left(0.97^{* *}\right.$ and $\left.0.88^{* * *}\right)$ as well as gross sugar $\%\left(0.97^{* * *}\right.$ and $\left.0.90^{* *}\right)$ in the first and second season, respectively. Also, positive and highly significant correlation coefficients were seen between root yield and root fresh wt. $\left(0.94^{* *}\right.$ and $\left.0.90^{* * *}\right)$ as well as between root yield and gross sugar percentage $\left(0.89^{* *}\right.$ and $\left.0.61^{* *}\right)$. In the two seasons, respectively, positive and highly significant correlations were also obtained between gross sugar yield and each of root length $\left(0.81^{* *}\right.$ and $\left.0.69^{* *}\right)$ also, root diameter $\left(0.76^{* *}\right.$ and $\left.0.78^{* *}\right)$. It is worthnoting that gross sugar yield showed the highest positive correlation with root yield and gross sugar (\%)

Egypt. J. Agron. 38, No.2 (2016) 
indicating their economic importance. The results obtained in Table 6 clarify that there are three traits, i.e. extractable sugar $\%$, root yield and leaf area index in both season, as well as root diameter in the second season were significantly $(\mathrm{P} \leq$ 0.001 ) contributed to variation in extractable sugar yield.

Generally, under the condition of this study, it could be recommended that fertilizing Demo $\left(\mathrm{V}_{2}\right)$ variety of sugar beet with $50 \mathrm{~kg} \mathrm{~K} / \mathrm{fad}\left(\mathrm{K}_{3}\right)$ and sprayed with micronutrients mixtures $\left(B+Z n+M n\left(M_{4}\right)\right.$, increased the productivity and quality of sugar beet plants, and root yield was strongly correlated with gross sugar yield and gross sugar percentage.

TABLE 5. A matrix of simple correlation coefficient between gross sugar yield and other important traits estimated in 2013/14 and 2014/15 seasons.

\begin{tabular}{|c|c|c|c|c|c|c|c|c|}
\hline \multicolumn{2}{|c|}{ Characters } & \multirow{2}{*}{$\begin{array}{c}\text { Seasons } \\
2013 / 14\end{array}$} & \multirow{2}{*}{$\frac{1}{1}$} & \multirow[t]{2}{*}{2} & \multirow[t]{2}{*}{3} & \multirow[t]{2}{*}{4} & \multirow[t]{2}{*}{5} & \multirow[t]{2}{*}{6} \\
\hline & Gross sugar yield & & & & & & & \\
\hline 1. & $\left.(\mathrm{t} \mathrm{fad})^{-1}\right)$ & $2014 / 15$ & 1 & & & & & \\
\hline \multirow{2}{*}{2.} & \multirow{2}{*}{$\begin{array}{l}\text { Root yield } \\
\left(\mathrm{t} \mathrm{fad}^{-1}\right)\end{array}$} & $2013 / 14$ & $0.97 * *$ & 1 & & & & \\
\hline & & $2014 / 15$ & $0.88 * *$ & 1 & & & & \\
\hline \multirow{2}{*}{3.} & \multirow{2}{*}{ Gross sugar $(\%)$} & $2013 / 14$ & $0.97 * *$ & $0.89 * *$ & 1 & & & \\
\hline & & $2014 / 15$ & $0.90 * *$ & $0.61^{* *}$ & 1 & & & \\
\hline \multirow{2}{*}{4.} & \multirow{2}{*}{$\begin{array}{l}\text { Root fresh weight } \\
\left(\text { g plant }^{-1}\right)\end{array}$} & $2013 / 14$ & $0.94 * *$ & $0.94 * *$ & $0.89 * *$ & 1 & & \\
\hline & & $2014 / 15$ & $0.88^{* *}$ & $0.90^{* *}$ & $0.70 * *$ & 1 & & \\
\hline \multirow{2}{*}{5.} & \multirow{2}{*}{ Root length (cm) } & $2013 / 14$ & $0.81 * *$ & $0.76^{* *}$ & $0.81^{* *}$ & $0.77 * *$ & 1 & \\
\hline & & $2014 / 15$ & $0.69 * *$ & $0.69 * *$ & $0.56^{* *}$ & $0.73 * *$ & 1 & \\
\hline \multirow{2}{*}{6.} & \multirow{2}{*}{$\begin{array}{l}\text { Root diameter } \\
(\mathrm{cm})\end{array}$} & $2013 / 14$ & $0.76 * *$ & $0.74 * *$ & $0.78 * *$ & $0.78 * *$ & $0.87 * *$ & 1 \\
\hline & & $2014 / 15$ & $0.78^{* * *}$ & $0.78 * *$ & $0.66^{* *}$ & $0.81 * *$ & $0.75 * *$ & 1 \\
\hline
\end{tabular}

TABLE 6. Correlation coefficient (r), coefficient of determination $\left(R^{2}\right)$ and standard error of the estimates (SEE) for predicting extractable sugar yield (t/fad) in $2013 / 14$ and $2014 / 15$ seasons.

\begin{tabular}{|l|c|c|c|c|c|}
\hline Season & $\mathbf{r}$ & $\mathbf{R}^{2}$ & SEE & Sig. & \multicolumn{1}{c|}{ Fitted equation } \\
\hline $2013 / 14$ & 0.996 & 0.991 & 0.2023 & $* * *$ & $\begin{array}{l}\text { Extractable sugar yield }=-6.724+ \\
0.438 \text { extractable sugar } \%+0.164 \\
\text { root yield }-0.054 \text { leaf area index }\end{array}$ \\
\hline $2014 / 15$ & 0.996 & 0.991 & 0.186 & $* * *$ & $\begin{array}{l}\text { Extractable sugar yield }-5.564+ \\
0.356 \text { extractable sugar } \%+0.173 \\
\text { root yield }+0.103 \text { leaf area index }- \\
0.069 \text { root diameter }\end{array}$ \\
\hline
\end{tabular}




\section{References}

Abdel-Mawly, S.E. and Zanouny, I. (2004) Response of sugar beet (Beta vulgaris L.) to potassium application and irrigation with saline water. Ass. Univ. Bull. Environ. Res. 7 (1), 123-136.

Abo-Shady, Kh.A., Hilal, Samia M.M. and El-Shere, E.El.M. (2010) Yield and quality of sugar beet crop as affected by irrigation interval, cultivars and potassium fertilization in North Delta. J. Agric. Res. Kafer El-Sheikh Univ. 36 (4), 361-376.

Amer, M.A., Attalah, M.Z., Ibrahim M.F. and E.L-Taweel, F. (2004) Effect of potassium fertilizer on mineral contents and some biological components of ten sugar beet varieties. J. Agric. Sci., Mansoura Univ.. 29(6), 2963-2978.

Barłóg, P., Nowacka, A. and Błaszyk, R. (2016) Effect of zinc band application on sugar beet yield, quality and nutrient uptake. Plant Soil Environ. 62(1), 30-35.

Cooke, D.A and Scott, R.K. (1993) "The Sugar Beet Crop". Chapman and Hall, London, pp. 262-265.

El-Harriri, D.M. and Gobarah, Mirvat, E. (2001) Response of growth, yield and quality of sugar beet to nitrogen and potassium fertilizers under newly reclaimed sandy soil. J. Agric. Sci. Mansoura Univ. 26 (10), 5895-5907.

Gobarah, Mirvat E. and Mekki, B.B. (2005) Influence of boron application on yield and juice quality of some sugar beet cultivars grown under saline soil conditions. J. App. Sci. Res. 1(5), 373-379.

Gobarah, Mirvat E., Tawfik, M.M., Zaghloul,Sahar M. and Amin, Gehan A. (2014) Effect of combined application of different micronutrients on productivity and quality of sugar beet plants (Beta vulgaris L.). Intern. J.Plant \& Soil Sci. 3(6), 589-598.

Gomez, K.A. and Gomez, A.A. (1984) "Statistical Procedures for Agricultural Research”. Book John Willey and Sons Inc., New York.

Harvey, G.W and Dotton, J.V. (1993) Root quality and processing In: "The Sugar Beet Crop Science into Practice”, D.A. Cooke and Scatt (Ed.), pp. 571-617. Chapman \& Hall. ISBN041225132.

Jaszczolt, E. (1998) Effect of two methods of fertilizing sugar beet with trace elements on the yields of roots and sugar. Gazeta-Cukrownicza, 106, 232-234.

Kobraee, S., Mohamadi, G.N., Heidari, S.H., Kajori, F.D. and Delkhosh, B. (2011) Influence of micronutrient fertilizer on soybean nutrient composition. Indian J. Sci. Technol. 4(7), 763-769.

Masri, M. I. (2008) Genotype $\times$ environment interaction and stability analysis in sugar beet. Proceedings of Meeting the Challenges of Sugar Crops and Integrated Industries in Developing Countries, Al-Arish, Egypt, pp. 186-191. 
Masri, M. I. and Hamza, M. (2015) Influence of foliar application with micronutrients on productivity of three sugar beet cultivars under drip irrigation in sandy soils. World J. of Agri. Sci. 11 (2), 55-61.

McGinnus, R.A. (1971) “Sugar Beet Technology” $2^{\text {nd }}$ ed. Sugar Beet Development Foundation, Fort., Color, U.S.A.

Mehrandish, M., Moeini, M.J. and Armin, M. (2012) Sugar beet (Beta vulgaris L.) response to potassium application under full and deficit irrigation. European $J$. Experimental Biology, 2 (6), 2113-2119.

Mekdad, A. A. A. (2015) Sugar beet productivity as affected by nitrogen fertilizer and foliar spraying with boron. Int. J. Curr. Microbiol. App. Sci. 4(4),181-196.

Mekdad, A.A.A and Rady, M.M (2016) Response of Beta vulgaris L. to nitrogen and micronutrients in dry environment. Plant Soil Environ. 62(1), 23-29.

Mekki, B.B. (2014) Root yield and quality of sugar beet (Beta vulgaris L.) in response to foliar application with urea, zinc and manganese in newly reclaimed sandy soil. American-Eurasian J. Agric. \& Environ. Sci. 14 (9), 800-806.

Mousavi, S. R., Galavi, M. and Ahmadvand, G. (2007) Effect of zinc and manganese foliar application on yield, quality and enrichment on potato (Solanum tuberosum L.). Asian J. Plant Sci. 6,1256-1260.

Nafei, A.I., Osman, A.M.H. and El-Zeny, Maha M. (2010) Effect of plant densities and $\mathrm{K}$ fertilization rates on yield and quality of sugar beet crop in sandy reclaimed soils. J. Plant Prod., Mansoura Univ. 1 (2), 229-237.

Nasr, M.I. and Abd El-Razek, A.M. (2008) Sugar beet performance under newly reclaimed soils conditions of Sinai, Egypt. Sugar Tech. 10(3), 210-218.

Neamatollahi, E., Khademosharieh, M.M., Darban, A.S. and Jahansuz, M.R. (2013) Application of different amounts of $\mathrm{ZnSO}_{4}$ in five varieties of sugar beet. Adva. Environl. Biol. 7(6), 1113-1116.

Neseim, M.R., Amin, A.Y. and El-Mohammady, M.M.S. (2014) Effect of potassium applied with foliar spray yeast on sugar beet growth and yield under drought stress. Global Adv. Res. J. Agric. Sci. 3, 211-222.

Nitoses, R.E. and Evans, H.G. (1969) Effect of univalent cations on the activity of particulate starch synthase. Plant Physiol. 44, 1260-1266.

Ouda , Sohier M.M. (2001) Response of sugar beet to N and K fertilizers levels under sandy soil conditions. Zagazig J. Agric. Res. 28(2), 275-297.

Refay, Y. A. (2010) Root yield and quality traits of three sugar beet (Beta vulgaris L.) varieties in relation to sowing date and stand densities. World J. Agric. Sci. 6 (5), 589594.

Russell, T.J., John, T.A., George, E.R. and George, R.H. (1971) "Advances in Sugar Beet Production”. The Iowa State Univ. Press, Ames, Iowa, USA .

Egypt. J. Agron. 38, No.2 (2016) 
Safina, S.A., Hassanin, M.A., EL-Metwally, EL-Met. A. and Elsherbini, N.R. (2012) Sowing date and plant density influences on yield and quality of some sugar beet varieties grown in sandy soils under drip irrigation system. J. Egypt. Acad. Soc. Environ. Develop. 13 (2), 73-85.

Salami, M. and Saadat, S. (2013) Study of potassium and nitrogen fertilizer levels on the yield of sugar beet in jolge cultivar. J. Nov. Appl. Sci. 2 (4), 94-100.

Sheikh Aleslami, R. (1997) "Laboratorial Methods and Their Application to Control Food and Sugar Industries Process" Mersa Publications, Tehran, Iran.

Wang, X. G., Hua, Z. X., Ji, J. C., Hong, L.C., Shan, C., Di, W., Qiu, C. Y., Qiu, Y. H. and Yan, W.C. (2015) Effects of potassium deficiency on photosynthesis and photoprotection mechanisms in soybean (Glycine max (L.) Merr.). Journal of Integrative Agriculture, 14, 856-863.

Watson, D. J. (1958) The dependence of net assimilation rate on leaf area index. Ann. Bot. N. S. 22, 37-54.

Yarnia, M., Beam, M.B.K., Rabat, H.K., Tabriz, E.F.M. and Hassan panah, D. (2008) Effects of complete micronutrients and their application method on root yield and sugar content of sugar beet cv. Rassoul. J. Food, Agric. and Environl. 6(3\&4), 341-345.

Zengin, M., Gökmen, F., Yazici, M.A. and Gezgin, S. (2009) Effects of potassium, magnesium, and sulphur containing fertilizers on yield and quality of sugar beets (Beta vulgaris L.). Turk. J. Agric. 33, 495-502.

(Received 19/5/2016; accepted $9 / 8 / 2016)$ 


\section{أداء صنفين من بنجر السكر تحت تأثير التسميد البوتاسى والرش بأش الورقى بالمغذيات الصغرى بنجين}

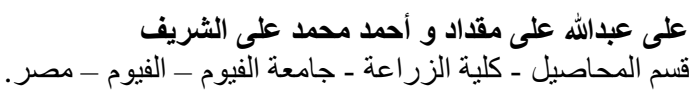

أجريت تجربنين حقليتين فى مزرعة كلية الزراعة بالفيوم بمنطة دمو - جامعة

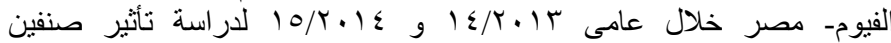

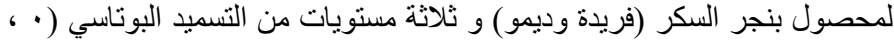

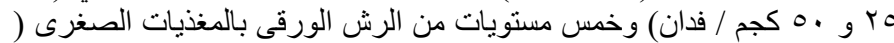

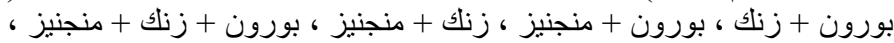

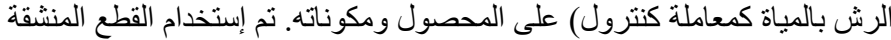

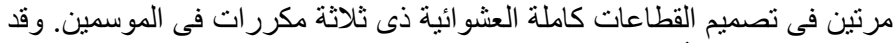

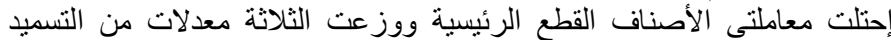

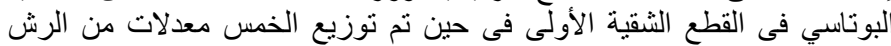

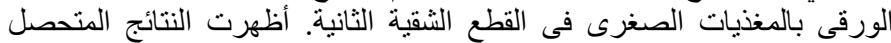

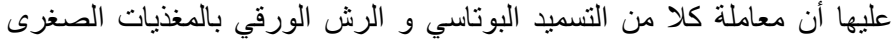

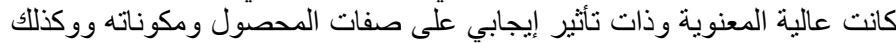

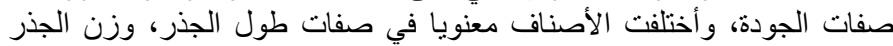

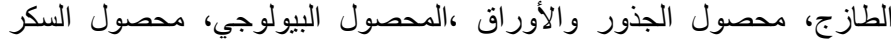
الظاهرى و المستخلص ، فضلا عن دليل الحصاد في كلا الموسمين.

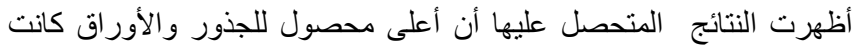

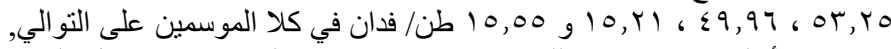

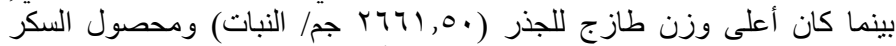

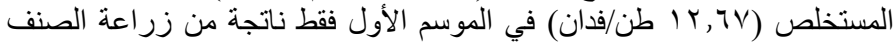

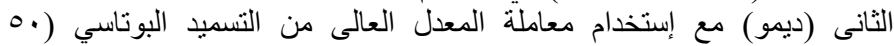

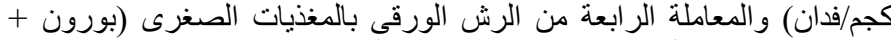

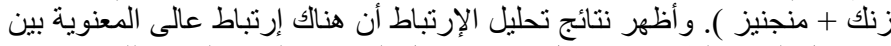

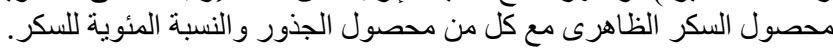

